\title{
Termografia aktywna jako nowa metoda badań nieniszczących połączeń zakładkowych spawanych laserowo
}

\section{Active thermography as a new non-destructive testing method of laser welded lap joints}

\section{Streszczenie}

W artykule przedstawiono zastosowanie termografii aktywnej do badań nieniszczących połączeń zakładkowych blach spawanych laserowo bez pełnego przetopienia. Opisano opracowaną metodologię badań, sposób wytworzenia połączeń próbnych oraz zastosowane stanowisko badawcze. Uzyskane obrazy termograficzne zostały poddane analizie polegającej na wyznaczeniu maksymalnego kontrastu temperaturowego. Ocenę wykonanych połączeń przeprowadzono na podstawie analizy makrostruktury wybranych przekrojów poprzecznych próbek. Na podstawie wyników badań termograficznych stwierdzono, że zaproponowana metoda może być $z$ powodzeniem zastosowana do nieniszczących badań połączeń zakładkowych spawanych laserowo.

Słowa kluczowe: termografia aktywna, połączenia zakładkowe, badania nieniszczące

\section{Abstract}

The application of active thermography for non-destructive testing of laser welded lap joints (with partial joint penetration) was presented in this article. The methodology, specimen preparation and applied apparatus were described. Thermal images of the specimens obtained during experiments were analyzed using procedure based on maximum thermal contrast determination. Prepared laser welded lap joints were examined using typical macro image analysis of selected cross sections of joints. The obtained experimental results showed that considered method has a great potential to be successfully applied for non-destructive testing of laser welded lap joints.

Keywords: active thermography, lap joints, non-destructive testing

\section{Wstęp}

Połączenia zakładkowe spawane laserowo są obecnie coraz częściej stosowane m.in. w branży motoryzacyjnej przy wytwarzaniu karoserii i innych elementów samochodu. W ostatnich latach wysokowydajne, nowoczesne metody spawania laserowego w wielu przypadkach zastąpiły z bardzo dobrymi efektami tradycyjną metodę rezystancyjnego zgrzewania punktowego. Wynika to z powszechnie znanych, licznych za-

let spawania laserowego, takich jak np.: duża gęstość mocy, duża elastyczność procesu, duża prędkość spawania przy małych odkształceniach samego elementu,

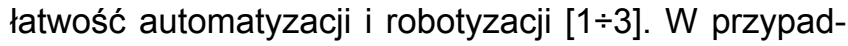
ku wykonywania połączeń zakładkowych, technologia spawania laserowego umożliwia stosowanie zmniejszonej szerokości zakładki w stosunku do tej, która wymagana jest podczas zgrzewania rezystancyjnego (rys. 1) ze względu na rozmiary elektrod i konieczny naddatek w celu uniknięcia niepożądanego zjawiska wyprysku.

Dr inż. Sebastian Pawlak - Politechnika Śląska w Gliwicach, dr inż. Maciej Różański, dr inż. Sebastian Stano - Instytut Spawalnictwa w Gliwicach, mgr Grzegorz Muzia - Instytut Metali Nieżelaznych w Gliwicach. 

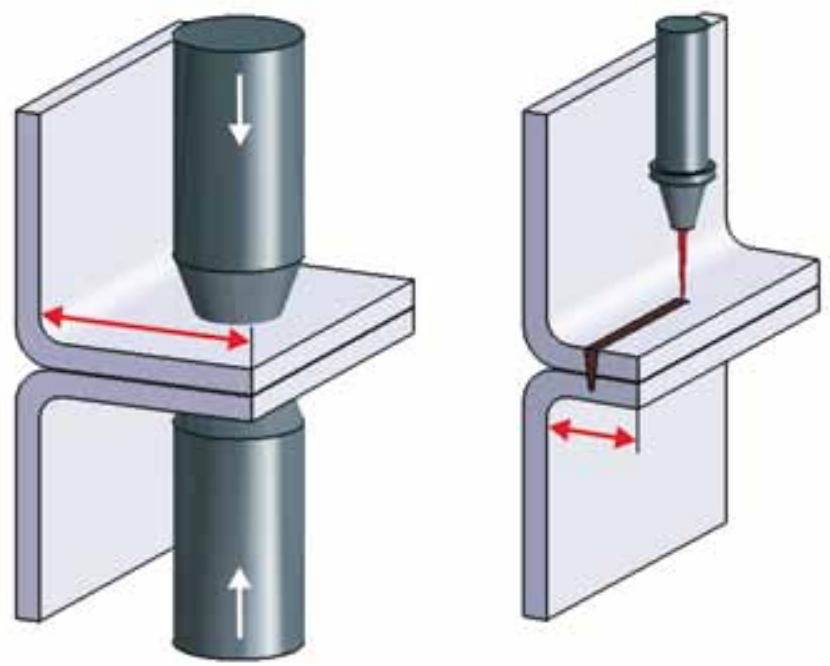

Rys. 1. Poglądowe porównanie szerokości zakładki w zależności od technologii łączenia elementów karoserii: a) zgrzewanie rezystancyjne punktowe, b) spawanie laserowe

Fig. 1. Comparison of lap width depending on joining technology of car-body parts: a) resistance spot welding, b) laser welding

Mniejsza ilość użytego materiału, wynikająca z zastosowania mniejszej szerokości połączenia zakładkowego, przyczynia się do obniżenia masy karoserii, spełniając tym samym jeden $z$ aktualnych wymogów branży motoryzacyjnej w zakresie redukcji masy własnej pojazdu. Obserwowane obecnie efekty dążenia do zmniejszenia masy pojazdu są w znacznej mierze wynikiem realizowanego $\mathrm{w}$ przeszłości projektu ULSAB (ang. UltraLight Steel Auto Body), w którym zaproponowano zredukowanie przekrojów elementów konstrukcyjnych karoserii przez zastąpienie dotychczas stosowanych stali nowymi, zaawansowanymi stalami o dużej wytrzymałości typu AHSS (ang. Advanced High Strength Steels) oraz użycie technologii spawania laserowego do łączenia stalowych elementów składowych karoserii (np. elementów typu Tailored Welded Blanks) $[1,4,5]$. W wyniku zastosowania spawania laserowego można uzyskać poprawę sztywności całej karoserii ze względu na możliwość wytworzenia złącza ciągłego na całej długości zakładki. Istnieje także możliwość zaprojektowania korzystnego rozkładu naprężeń przenoszonych przez elementy łączone poprzez odpowiedni dobór długości lub/i kształtu złącza. Zaletą technologii spawania laserowego jest również możliwość dostępu do tych obszarów karoserii, gdzie duże gabarytowo urządzenia do zgrzewania elektrooporowego są bezużyteczne. Ponadto, stosując spawanie laserowe do połączeń zakładkowych, wystarczy dostęp tylko do jednej z łączonych blach, co daje dodatkowe możliwości, które obecnie brane są pod uwagę na etapie projektowania procesu technologicznego łączenia elementów składowych karoserii [6].

Pomimo wymienionych przykładowych zalet technologii spawania laserowego, pewnym problemem okazało się samo spawanie ocynkowanych blach karoseryjnych, w szczególności w przypadku połączenia zakładkowego z „zerową" szczeliną pomiędzy łączo- nymi blachami. W uproszczeniu problem ten polega na tym, że podczas spawania ocynkowanych blach stalowych cynk odparowuje, gdyż jego temperatura wrzenia $\left(906^{\circ} \mathrm{C}\right)$ jest znacząco mniejsza od temperatury topnienia stali podłoża (ponad $1500^{\circ} \mathrm{C}$ ) - cynk w postaci pary pod ciśnieniem „wyrzuca” ciekłą stal z jeziorka spawalniczego. Efektem tego zjawiska są niezgodności spoiny (np. pęcherze i pory), które w sposób istotny obniżają wytrzymałość mechaniczną połączenia. Sposoby zapobiegania temu zjawisku stanowią odrębne zagadnienie opisywane m.in. w [7, 8]. Poza przytoczonym utrudnieniem, przy spawaniu laserowym blach z powłoka cynkowa, podczas wytwarzania połączeń zakładkowych mogą wystąpić również inne niezgodności powstałe $\mathrm{w}$ czasie realizacji ustalonego procesu, jak np. lokalny brak połączenia obu blach, którego przyczyną może być m.in. chwilowe wahanie mocy wiązki laserowej. Do niezgodności tych zaliczyć można przypadki zilustrowane na rysunkach $2 \mathrm{a}$ i $2 \mathrm{~b}$.

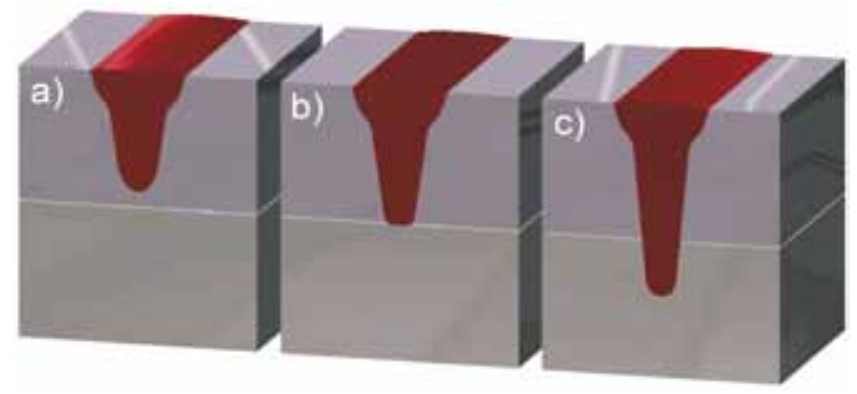

Rys. 2. Przypadki uzyskiwanej głębokości wtopienia przy spawaniu laserowym blach na zakładkę: a) brak przetopienia na wskroś górnej blachy, b) pełne przetopienie górnej blachy z jednoczesnym „przyklejeniem" ciekłego metalu do blachy dolnej, c) połączenie prawidłowe Fig. 2. Cases of obtained penetration depth during laser welding of metal sheets in the lap joint configuration: a) lack of full penetration of top sheet, b) full penetration of top sheet where liquid metal touches the bottom sheet, $c$ ) correct joint

Często, ze względu na specyfikację danego elementu karoserii i niektórych części samochodu, konieczne jest uzyskanie połączenia bez przetopienia na wskroś, jak na rysunku 2c. Wynika to głównie z walorów estetycznych w przypadku elementów widocznych, gdyż jedynie ta blacha, na którą pada wiązka lasera, ma widoczną linię przetopienia na długości złącza. W każdym z przykładów jak na rysunku 2, z uwagi na to, że wygląd lica spoiny jest podobny (lub taki sam) i brak jest widocznej grani, nie ma możliwości oceny tego typu połączenia metodą wizualną. Do oceny ciągłości materiałowej połączeń spawanych stosuje się techniki ultradźwiękowe, lecz istotnym problemem jest tu przede wszystkim wydajność, która ma kluczowe znaczenie przy kontroli jakości w produkcji seryjnej. Poza zdecydowanie lepszą estetyką połączeń zakładkowych bez pełnego przetopienia, nie ulega przy tym uszkodzeniu powłoka cynkowa na powierzchni zewnętrznej blachy nieprzetopionej na wskroś, co z kolei minimalizuje negatywny wpływ łączenia na właściwości antykorozyjne, który jest istotnym problemem będącym przedmiotem licznych naukowych analiz [9]. 
W praktyce produkcyjnej wytwarzania karoserii i innych części samochodu odnotowano przypadki, w których - pomimo ustalonych, prawidłowo dobranych warunków procesu spawania laserowego - występuje miejscowy brak połączenia obu blach, co prowadzi do obniżenia wytrzymałości mechanicznej całego produktu. Z tego względu przemysł motoryzacyjny „zgłasza” zapotrzebowanie na efektywną metodę badań nieniszczących połączeń zakładkowych spawanych laserowo.

W ostatnich latach obserwuje się znaczny wzrost zainteresowania termografią aktywną jako nieniszczącą metodą badań materiałów inżynierskich. Do tej pory stosowano tę metodę z bardzo dobrymi efektami głównie do badań materiałów kompozytowych dla przemysłu lotniczego, w którym występuje problem kontroli elementów o dużych gabarytach, gdzie tradycyjne metody (np. techniki ultradźwiękowe) są wprawdzie skuteczne, ale jednocześnie mało wydajne [10]. Wcześniejsze autorskie wyniki badań dowiodły przydatności termografii aktywnej w ocenie jakości zakładkowych połączeń lutowanych, gdzie analizowano za pomocą tej metody stopień wypełnienia ciekłym lutem przestrzeni (szczeliny) pomiędzy łączonymi blachami [11].

W odpowiedzi na zapotrzebowanie branży motoryzacyjnej i ze względu na wcześniejsze doświadczenia w zakresie badań nieniszczących połączeń nierozłącznych z zastosowaniem termografii aktywnej, autorzy podjęli badania eksperymentalne mające na celu sprawdzenie moźliwości zastosowania tej metody do oceny jakości połączeń zakładkowych spawanych laserowo bez pełnego przetopienia. Niniejszy artykuł stanowi kontynuację rozpoczętych wcześniej prac nad rozwojem termografii aktywnej jako nieniszczącej metody badań połączeń nierozłącznych.

\section{Badania własne}

\section{Cel i metodyka badań}

W celu analizy możliwości zastosowania termografii aktywnej do badań połączeń zakładkowych blach spawanych laserowo bez pełnego przetopienia, opracowano plan badań uwzględniający: dobór materiału do badań, sposób wytworzenia połączeń próbnych (w tym dobór parametrów procesu spawania laserowego), sposób analizy wyników badań termograficznych oraz dobór metody oceny jakości połączeń próbnych w celu właściwej interpretacji wyników badań termograficznych. Zgodnie z postawionym celem eksperymentu, badaniom poddano próbki zawierające: złącze wykonane wadliwie w sposób zamierzony (brak ciągłości przetopienia blach), złącze wykonane prawidłowo (celem porównania obrazów termograficznych podczas analizy wyników). Szczegółowe dane dotyczące sposobu wytworzenia próbek i symulacji wady złącza próbnego zamieszczono w kolejnym punkcie. Uwzględniając zasadę prowadzenia badań metodą termografii aktywnej, założono że ciągłość materia- łowa (lub jej brak) na długości linii złącza spawanego laserowo będzie miała wystarczający wpływ na - aktywowany dla celów badawczych - nieustalony przepływ ciepła, którego efektem jest podlegający interpretacji rozkład temperatury na powierzchni próbki. Ilościowej oceny rozkładu temperatury dokonano na podstawie wyznaczonej wartości maksymalnego kontrastu temperaturowego. Jakość uzyskanych złączy (głębokość przetopienia w trzech wybranych miejscach charakterystycznych) została potwierdzona przez analizę makrostruktury przekrojów poprzecznych złącza.

\section{Przygotowanie próbek do badań}

Zgodnie z postawionym celem eksperymentu przygotowano dwie próbki do badań; pierwszą (oznaczoną jako próbka 1) - charakteryzującą się miejscowym brakiem ciągłości wtopienia w dolną blachę na długości linii złącza; drugą (oznaczoną jako próbka 2) - posiadającą ciągłość wtopienia na całej długości linii złącza. Umownie przyjęto, że próbka z ciągłością przetopienia dolnej blachy stanowić będzie próbkę referencyjną ze złączem wykonanym prawidłowo, a próbka o braku ciągłości przetopienia dolnej blachy symulować będzie próbkę wadliwą. Wytworzone połączenia zakładkowe składały się z dwóch blach o grubości 2,5 mm, w kształcie kwadratu o boku 100 mm, ułożonych osiowo jedna na drugiej. Próbki te wykonano w Instytucie Spawalnictwa w Gliwicach na zrobotyzowanym stanowisku do spawania laserowego. Stanowisko to wyposażone jest w laser na ciele stałym o maksymalnej mocy wiązki równej 12 kW. Głowica robocza CFO firmy Trumpf zawiera soczewkę skupiającą o długości ogniskowej 300 mm i umożliwia uzyskanie średnicy ogniska wiązki laserowej 0,45 mm.

W celu uzyskania wyżej opisanych złączy zaprogramowano trajektorię przemieszczenia głowicy po linii prostej o długości $60 \mathrm{~mm}$, składającą się z trzech stref, dla których - przy stałej prędkości przesuwu głowicy - możliwe było ustawienie różnych poziomów wartości mocy wiązki laserowej (zgodnie z rys. 3).

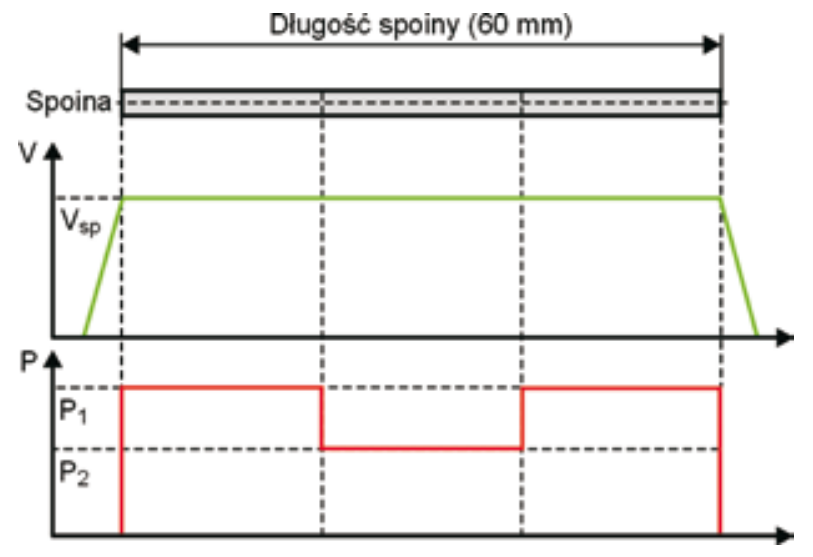

Rys. 3. Schematy przebiegów prędkości spawania (V) i mocy wiązki laserowej $(P)$ wzdłuż ściegu spoiny podczas wykonywania połączeń próbnych

Fig. 3. Schemes of welding speed diagram (V) and laser beam power diagram $(P)$ along run of joint during preparation of specimens 
Ze względu na to, że dodatkowym celem eksperymentu było badanie połączeń, dla których ocena wizualna wyniku procesu spawania nie jest możliwa, dobrano parametry procesu (tabl. I) spawania laserowego tak, aby nie uzyskać pełnego przetopienia (widocznej grani spoiny) od strony zewnętrznej dolnej blachy w obu próbkach do badań.

Tablica I. Parametry procesu spawania laserowego złączy próbnych Table I. Parameters of laser welding used for specimens preparation

\begin{tabular}{|c|c|c|c|c|c|}
\hline $\begin{array}{c}\text { Oznaczenie } \\
\text { próbki }\end{array}$ & $\begin{array}{c}\text { Moc } \\
\mathrm{P} 1 \\
\mathrm{~kW}\end{array}$ & $\begin{array}{c}\text { Moc } \\
\mathrm{P} 2 \\
\mathrm{~kW}\end{array}$ & $\begin{array}{c}\text { Prędkość } \\
\text { spawania } \\
\mathrm{m} / \mathrm{min}\end{array}$ & $\begin{array}{c}\text { Położenie } \\
\text { ogniska } \\
\text { wiązki } \\
\text { laserowej }\end{array}$ & $\begin{array}{c}\text { Natężenie } \\
\text { wypływu } \\
\text { gazu (argon) } \\
\text { osłonowego } \\
\text { l/min }\end{array}$ \\
\hline 1 & 2,5 & 1,0 & 2,0 & 0 & 8 \\
\hline 2 & 2,5 & 2,5 & 2,0 & 0 & 8 \\
\hline
\end{tabular}

Próbki przed badaniami termograficznymi zostały pokryte z jednej strony czarną matową farbą o współczynniku emisyjności równym ok. 0,93, celem wyeliminowania przypadkowych odbić światła w warunkach prowadzonego eksperymentu i ujednolicenia emisyjności powierzchni, na której przewidziano rejestrację obrazów.

\section{Stanowisko badawcze i przebieg badań termograficznych}

Badania termograficzne metodą aktywną wykonano w Instytucie Metali Nieżelaznych w Gliwicach na stanowisku badawczym własnej konstrukcji [12]. Stanowisko to zaprojektowano tak, aby możliwe było precyzyjne ustawienie i zachowanie jednakowych warunków pomiarowych dla każdej próbki badanej. Realizowane jest to dzięki zastosowaniu przesłony ruchomej mającej za zadanie czasowe odsłanianie (na czas nagrzewania) powierzchni próbki w celu zainicjowania nieustalonego przepływu ciepła. Napęd przesłony ruchomej sterowany jest programowalnym sterownikiem PLC, co umożliwia precyzyjne ustawienie czasu nagrzewania $z$ dokładnością ok. $0,1 \mathrm{~s}$ (w eksperymencie tym czas nagrzewania wynosił 0,8 s). Powtarzalność warunków pomiarowych, którą zapewnia opisywane stanowisko badawcze, jest wymagana w przypadku konieczności przeprowadzenia analizy porównawczej uzyskiwanych obrazów termograficznych. Do wymuszenia cieplnego użyto promiennika podczerwieni o mocy $1200 \mathrm{~W}$ i zakresie emitowanej fali elektromagnetycznej od 2 do $10 \mu \mathrm{m}$. Promiennik ten dobrano tak, aby jego powierzchnia robocza była większa od rozmiarów próbki w celu zapewnienia równomiernego nagrzewania. Sekwencje obrazów termograficznych rejestrowano kamerą termowizyjną ThermaCAM ${ }^{\mathrm{TM}}$ SC640 firmy Flir-systems, połączoną z komputerem klasy PC stanowiącym układ sterujący kamerą z poziomu oprogramowania Researcher Professional 2.9, które wykorzystywano również do analizy uzyskanych obrazów. Uproszczony schemat układu pomiarowego przedstawiono na rysunku 4.
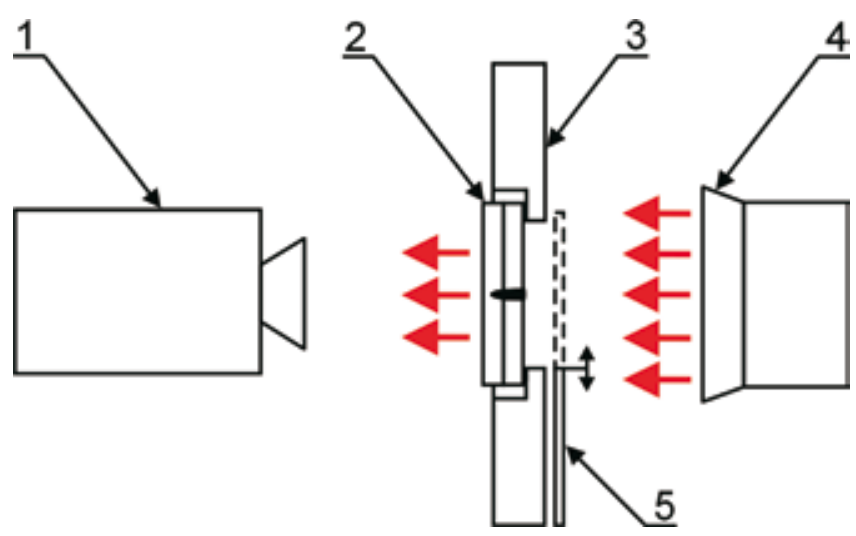

Rys. 4. Schemat układu pomiarowego; 1 - kamera termowizyjna, 2 - próbka badana, 3 - układ mocowania próbki, 4 - promiennik podczerwieni, 5 - przesłona ruchoma

Fig. 4. Scheme of measurement configuration; 1 - IR camera, 2 - specimen tested, 3 - specimen holder system, 4 - IR radiator, 5 - movable heat barrier

Obrazy termograficzne rejestrowano na powierzchni tej blachy, która nie została przetopiona na wskroś podczas spawania (blacha bez śladów wykonanego złącza na jej widocznej powierzchni zewnętrznej). Procedura pomiarowa, obejmująca aktywowany dla celów badawczych proces nieustalonego przepływu ciepła, odbywała się następująco: impulsowe nagrzewanie powierzchni próbki przez promieniowanie, przepływ ciepła w kierunku grubości próbki badanej, rejestracja obrazów termograficznych na powierzchni próbki przeciwległej do jej powierzchni nagrzewanej (począwszy od chwili rozpoczęcia procesu nagrzewania). Do analizy tak uzyskanych obrazów termograficznych zastosowano procedurę polegającą na wyznaczeniu maksymalnego kontrastu temperaturowego $\Delta \mathrm{T}(\mathrm{t})$ definiowanego jako różnica temperatury pomiędzy dwoma umownymi punktami; jeden punkt pochodzący z obszaru bez wady, drugi punkt pochodzący z obszaru zawierającego wadę.

\section{Analiza wyników badań}

W wyniku badań termograficznych otrzymano sekwencje obrazów, które poddano kolejno analizie polegającej na wyznaczeniu maksymalnego kontrastu temperaturowego na zdefiniowanych obszarach charakterystycznych wzdłuż linii złącza i porównaniu wyników dla obu próbek badanych. Na rysunkach 5 i 6 pokazano wybrane obrazy termograficzne zarejestrowane na powierzchni próbek 1 i 2 . Na rysunkach tych zamieszczono dodatkowo wykresy przedstawiające chwilowy rozkład temperatury wzdłuż linii złącza o długości $60 \mathrm{~mm}$, zaznaczonego białą poziomą linią prostą.

Obraz termograficzny powierzchni próbki 1 (rys. 5) wybrano jako najbardziej reprezentatywny ze względu na największą wartość kontrastu temperaturowego 


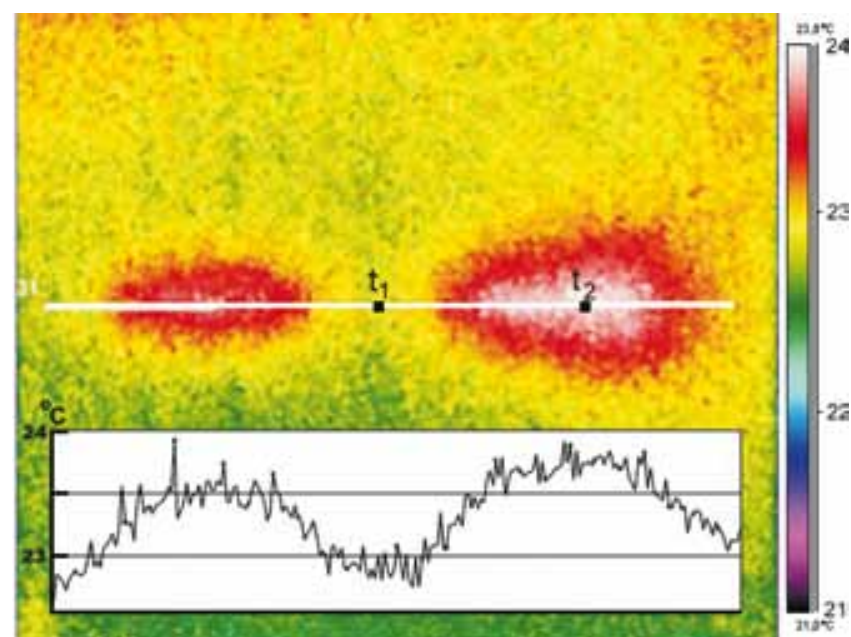

Rys. 5. Obraz termograficzny powierzchni próbki 1 (biała linia prosta zaznaczono położenie osi złącza); wykres liniowy przedstawia chwilowy rozkład temperatury wzdłuż linii złącza

Fig. 5. Thermal image of the surface of specimen 1 (white straight line indicates the position of joint axis); linear diagram shows a momentary temperature distribution along joint line

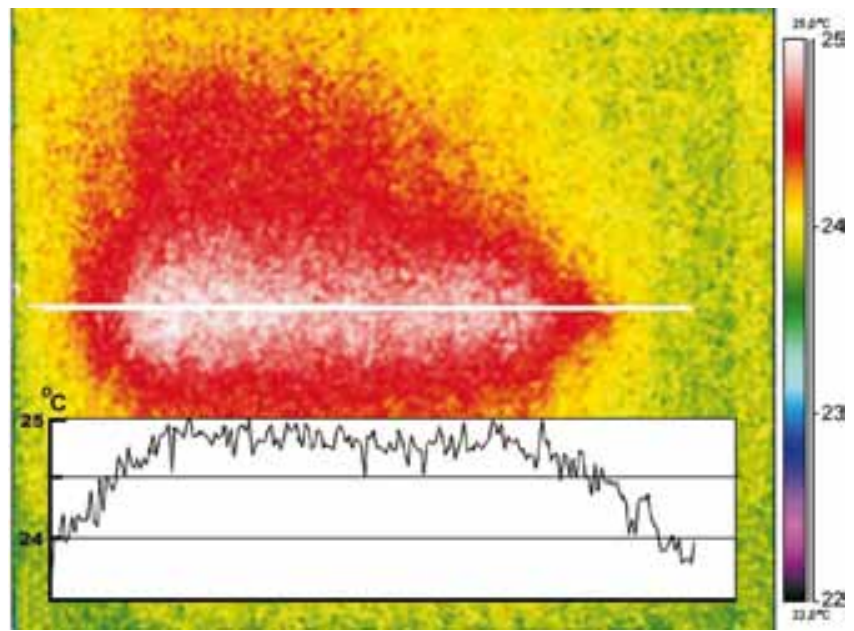

Rys. 6. Obraz termograficzny powierzchni próbki 2 (białą linią prostą zaznaczono położenie osi złącza); wykres liniowy przedstawia chwilowy rozkład temperatury wzdłuż linii złącza

Fig. 6. Thermal image of the surface of specimen 2 (white straight line indicates the position of joint axis); linear diagram shows a momentary temperature distribution along joint line

występującego wzdłuż linii złącza (wartość ta jest różnicą pomiędzy wartością $w$ punkcie $t_{1}$ - pochodzącą ze środka linii złącza, a wartością w punkcie $t_{2}$ - o wyraźnie szybszym wzroście temperatury). Na rysunku 7 pokazano uzyskane przebiegi zmian temperatury i kontrastu temperaturowego w czasie.

Dla próbki 1 uzyskano stosunkowo wysoką wartość maksymalnego kontrastu temperaturowego równą $0,9^{\circ} \mathrm{C}$ (rys. 7), co wskazuje na prawidłowo dobrane warunki wymuszenia cieplnego, czego efektem są przejrzyste i czytelne obrazy termograficzne, które mogą być z powodzeniem poddane interpretacji wzrokowej lub stosując me-tody analizy obrazu. $Z$ praktyki badań termograficznych wiadomo, że wartość kontrastu temperaturowego oscylująca wokół zera (dowolnej jednostki temperatury), w całym przedziale czasu rejestracji zmian temperatury, wskazuje na brak występowania

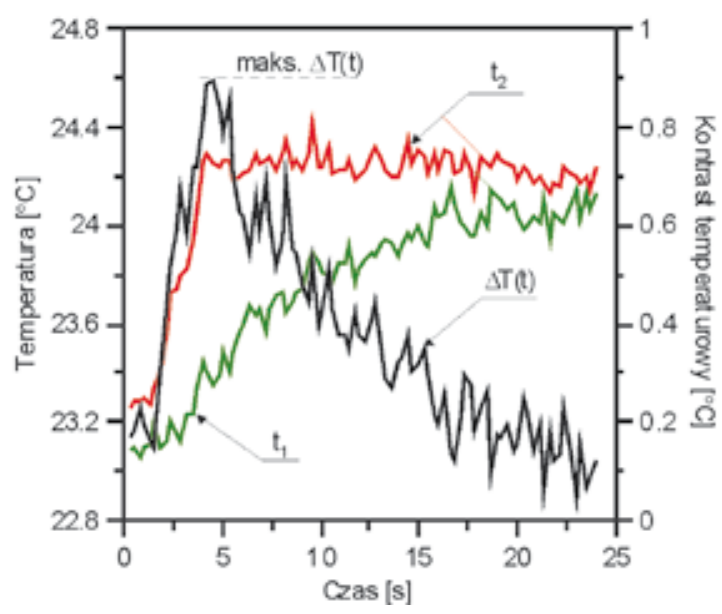

Rys. 7. Wykresy przebiegów zmian temperatury i kontrastu temperaturowego w czasie dla próbki 1; przebieg zmian temperatury w obszarze braku przetopienia $\left(t_{1}\right)$, przebieg zmian temperatury w obszarze przetopienia obu blach $\left(\mathrm{t}_{2}\right)$

Fig. 7. Diagrams of temperature changes and temperature contrast vs. time for specimen 1; temperature changes in the region of lack of penetration $\left(t_{1}\right)$, temperature changes in the region of full penetration of both sheets $\left(t_{2}\right)$

wady w materiale (jak dla próbki 2). Natomiast pojawienie się charakterystycznego wzrostu wartości kontrastu temperaturowego (np. o ok. 1 przyjętej jednostki temperatury) wskazuje na istnienie wady materiałowej - w rozpatrywanym przypadku jest to brak ciągłości złącza (próbka 1). Największą wartość kontrastu temperaturowego uzyskano po $4,5 \mathrm{~s}$, licząc od chwili zainicjowania nieustalonego przepływu ciepła w kierunku grubości próbki. Na obrazie termograficznym powierzchni próbki 1 (rys. 5) widoczne są dwa oddzielone od siebie pola o podwyższonej temperaturze usytuowane wzdłuż linii złącza, które wskazują na miejscowy brak ciągłości przetopienia obu blach. Powstałe pola o podwyższonej temperaturze są wynikiem efektywnego przepływu ciepła (czyste przewodzenie) w miejscach ciągłości materiałowej. Pomimo przedstawionej analizy wyników badań na podstawie oceny kontrastu temperaturowego, samo stwierdzenie wystąpienia nieciągłości złącza okazało się możliwe już podczas obserwacji wzrokowej rejestrowanych sekwencji obrazów termograficznych. W przypadku próbki 2, stanowiącej w tym eksperymencie próbkę referencyjną, uzyskano wartość kontrastu temperaturowego bliską zeru w czasie trwania całego pomiaru, co wskazuje na ciągłość przetopienia obu blach, która uwidacznia się jednorodnym rozkładem temperatury wzdłuż linii złącza. $\mathrm{Na}$ wybranym obrazie termograficznym powierzchni tej próbki widoczne jest jednolite pole o wyraźnie podwyższonej temperaturze (rys. 6).

W celu sprawdzenia poprawności interpretacji uzyskanych wyników badań termograficznych przeprowadzono ocenę jakości złączy testowych na podstawie analizy makrostruktury przekrojów poprzecznych prostopadłych do linii złącza $w$ trzech wybranych miejscach. Na rysunkach 8 i 9 pokazano widok powierzchni i makrostruktury przekrojów poprzecznych złączy odpowiednio dla próbek 1 i 2. 
Widoczny na rysunku 8 miejscowy brak ciagłości połączenia blach (przekrój B-B) w środkowej części próbki był przyczyną uzyskania obrazu termograficznego charakteryzującego się dwoma oddzielnymi obszarami o wyraźnie podwyższonej temperaturze. Z kolei widok przekroju A-A ujawnił kolejną wadę złącza próbki 1 w postaci pustki widocznej na wysokości styku obu blach łączonych, która powstała $w$ sposób niezamierzony (rys. 8). Obecność pustki w miejscu przetopienia blach spowodowała zmniejszenie efektywnej powierzchni złącza i dlatego prawdopodobnie na obszarze tym zarejestrowano wyraźnie mniejszą temperaturę od tej emperatury na obszarze złącza niezawierającego żadnej wady, co widać na obrazie termograficznym na rysunku 4. Można przypuszczać więc, że analizowana metoda badawcza, poza wykrywaniem całkowitego braku ciągłości materiałowej, pozwoli również na wykrywanie mniejszych wad, takich jak np. pustki lub pęcherze. Z kolei makrostruktury przedstawione na rysunku 9 potwierdzają założoną ciągłość przetopienia na całej długości linii złącza próbki 2. Efektem tej ciągłości była wysoka efektywność przepływu ciepła i wynikający z tego równomierny rozkład temperatury na powierzchni tej próbki (rys. 6).

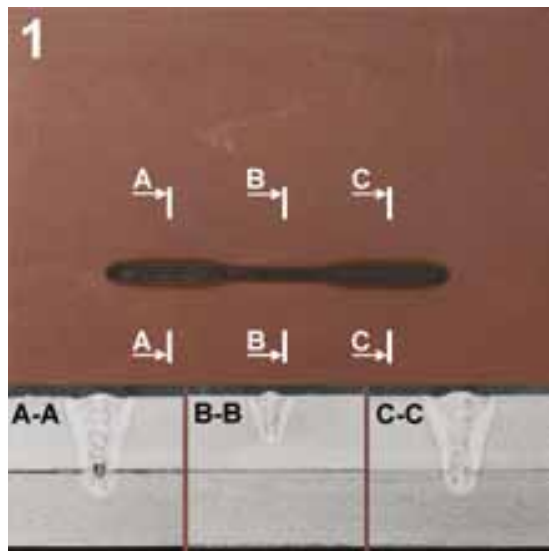

Rys. 8. Widok powierzchni próbki 1 oraz makrostruktury przekrojów poprzecznych w trzech wybranych miejscach złącza

Fig. 8. View of the surface of specimen 1 and macrostructures of cross-sections in three selected places of the joint
Przedstawione wyniki eksperymentalne wskazuja, że termografia aktywna może być rozpatrywana jako nowa metoda badań nieniszczących połączeń zakładkowych blach spawanych laserowo. Skuteczność analizowanej metody badawczej wynika z możliwości rejestracji rozkładu temperatury na powierzchni próbki, który jest efektem przepływu ciepła różniącego się w zależności od występującej ciągłości materiałowej złącza. Pomimo obiecujących rezultatów uzyskanych w warunkach laboratoryjnych na specjalnie zaprojektowanych próbkach, konieczne jest prowadzenie dalszych badań, np. uwzględniających również połączenia zawierające inne niezgodności, jak np. wadę charakteryzującą się pełnym przetopieniem jednej blachy, gdzie jednocześnie dochodzi do styku (,przyklejenia") roztopionego metalu $z$ drugą blachą (rys. 2b). W przypadku występowania takiego „przyklejenia” w obszarze o pożądanym połączeniu obu blach, ze względu na przypuszczalnie wysoką efektywność przewodzenia ciepła w miejscu tego styku, istnieje możliwość otrzymania rozkładu temperatury zbliżonego do tego, jaki uzyskuje się dla złącza prawidłowego, co doprowadzić może do błędnej interpretacji wyników. Z tego względu w przyszłych pracach planem badań objęte będą dodatkowo połączenia zakładkowe zawierające inne spotykane wady i na tej podstawie dokonana zostanie kompletna ocena efektywności rozwijanej metody badawczej.

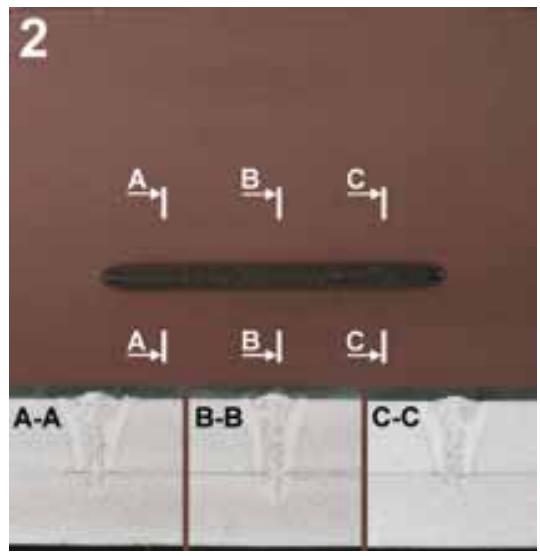

Rys. 9. Widok powierzchni próbki 2 oraz makrostruktury przekrojów poprzecznych w trzech wybranych miejscach złącza

Fig. 9. View of the surface of specimen 2 and macrostructures of cross-sections in three selected places of the joint

\section{Wnioski}

Opracowana metodologia badań umożliwiła uzyskanie wyników, które dowiodły przydatności termografii aktywnej w ocenie jakości połączeń zakładkowych blach spawanych laserowo bez pełnego przetopienia. W wyniku właściwie dobranych warunków wymuszenia cieplnego otrzymano sekwencje obrazów termograficznych, na podstawie których możliwe było jednoznaczne wskazanie obszaru próbki zawierającego symulowaną wadę w postaci nieciągłości złącza. Wada ta widoczna była podczas samej obserwa- cji wzrokowej rozkładu temperatury na powierzchni próbki na obrazie termograficznym, natomiast dalsza analiza wynikająca z procedury wyznaczania maksymalnego kontrastu temperaturowego umożliwiła wyrażenie wyników w sposób ilościowy. Zaproponowana metoda stanowi perspektywiczną, stosunkowo prostą w realizacji i szybką metodę badań nieniszczących połączeń zakładkowych blach spawanych laserowo bez pełnego przetopienia, która może być zastosowana w warunkach przemysłowych. 


\section{Literatura}

[1] Ma J., Kong F., Carlson B., Kovacevic R.: Mitigating zinc vapor induced weld defects in laser welding of galvanized high-strength steel by using different supplementary means. Welding Processes. Intech, New York, 2012, 117 $\div 138$.

[2] Cavusoglu N., Ozden H.: Automobile manufacturing using laser beam welding. Welding Journal, vol. 92, no. 2, 2013, $32 \div 37$

[3] Stano S.: New solid-state lasers and their application in weIding as generators of laser radiation, Welding International, $21 / 3,2007,173 \div 179$

[4] Grajcar A., Różański M., Stano S., Kowalski A., Grzegorczyk B.: Effect of heat input on microstructure and hardness distribution of laser welded Si-AI TRIP-type steel, Advances in Ma-

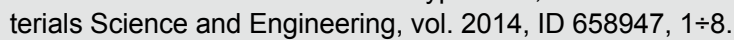

[5] UltraLight Steel Auto Body Final Report, First edition. American Iron and Steel Institute, Washington, USA, 1998.

[6] Mei L., Yi J., Yan D., Liu J., Chen G.: Comparative study on $\mathrm{CO}_{2}$ laser overlap welding and resitance spot welding for ga-

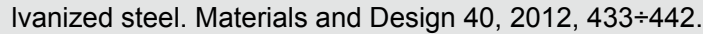

[7] Chen G., Mei L., Zhang M., Zhang Y., Wang Z.: Research on key influence factors of laser overlap welding of automobile body galvanized steel. Optics \& Laser Technology, vol. 45, $2013,726 \div 733$
[8] Kong F., Ma J., Carlson B., Kovacevic R.: Real-time monitoring of laser welding of galvanized high strength steel in lap joint configuration. Optics \& Laser Technology 44, 2012, $2186 \div 2196$

[9] Gruszczyk A., Sędek B.: Odporność korozyjna połączeń lutospawanych stali ocynkowanej. Przegląd Spawalnictwa nr 9/2007, 32 $\div 36$.

[10] Bates D., Smith G., Lu D., Hewitt J.: Rapid thermal non-destructive testing of aircraft components. Composites: Part B $31,2000,175 \div 185$

[11] Pawlak S., Różański M., Muzia G.: Zastosowanie termografii aktywnej do badań nieniszczących połączeń lutowanych. Przegląd Spawalnictwa $\mathrm{nr} 2 / 2013,24 \div 28$.

[12] Pawlak S.: Termograficzna metoda oceny rozkładu udziału włókien w kompozytach epoksydowo-węglowych (rozprawa doktorska). Politechnika Śląska w Gliwicach, Wydział Mechaniczny Technologiczny, Gliwice 2010.

\section{Odczyty techniczne}

\section{Organizowane przez Sekcję Spawalniczą OW SIMP, w II kwartale 2014 r., dostępne dla członków SIMP, NOT oraz wszystkich sympatyków spawalnictwa.}

\begin{tabular}{|c|c|}
\hline & $\begin{array}{c}\text { Wydział Inżynierii Produkcji Politechniki Warszawskiej } \\
\text { Gmach Nowy Technologiczny } \\
\text { Warszawa, ul. Narbutta 85, sala NT } 129 \\
\text { Dojazd tramwajami: } 17 \text { i } 33\end{array}$ \\
\hline $\begin{array}{l}\text { Data } \\
\text { i godzina }\end{array}$ & Prelegent, temat odczytu \\
\hline $\begin{array}{l}17-04-2014 \\
\text { godz. } 1700\end{array}$ & $\begin{array}{l}\text { Mgr inż. Andrzej Paczyński } \\
\text { Produkcja rurociągów aparatu do wydobywania ropy i gazu z dna morza }\end{array}$ \\
\hline $\begin{array}{l}22-05-2014 \\
\text { godz. } 1700\end{array}$ & $\begin{array}{l}\text { Mgr inż. Artur Gierwatowski, Szef Utrzymania Ruchu Huty ArcelorMittal Warszawa Sp. z o.o. } \\
\text { Nowoczesne technologie wytwarzania stali } \\
\text { Po odczynie odbędzie się uroczyste spotkanie z okazji „Dnia spawalnika” }\end{array}$ \\
\hline $\begin{array}{l}26-06-2014 \\
\text { godz. } 1700\end{array}$ & $\begin{array}{l}\text { Mgr inż. Zbigniew Czekała, Radwar SA } \\
\text { Radary pasywne }\end{array}$ \\
\hline
\end{tabular}

